\title{
Restoration in Objects and the Methodology of Intervention
}

\author{
PhD. Otjela Lubonja \\ European University of Tirana
}

\begin{abstract}
The purpose of the study is to highlight some of the ways of intervention that can be applied in various objects. In this study they treated theory- practical issues dealing with ways of intervention and essential elements in an object. Regards restoration as complex discipline which aims to value the monument as an historical proof. It's a monument evaluation by considering the appropriate amount to the component of historical document. Each population even each period of its historical development contains the ethnical and temporal stamp. The experience of our country in the restoration of popular dwelling makes possible that within the basis of achieved realizations other important criterion should be highlighted. The popular dwelling is distinguished for huge transformation that has passed throughout time. Each monument changes throughout time, but popular dwellings being a category directly connected to socio-economical conditions reflects those conditions. The dwelling is a construction with intensive and continuous exploitations which remains same even after being labeled as a monument. In the construction relatively weak materials and techniques are being used, highlighting the degradation of its constructive and architectonical elements. - Some of the problems we are going to treat are: Positions that should be held towards the changes that has passed the dwelling over time. 1.The partial or overall restoration ( seen in report with monument evaluation) The constructive and architectonical degraded elements; 2. The methodology of interference; 3. The techniques of cleaning; 4. The special criterion for dwelling restoration, for the simple fact that all monuments have its history and place in popular dwelling typology, find in most of the cases a common effectuation. So in the same monument can be applied different criterion in different parts of it. Every restoration is a special case.
\end{abstract}

Keywords: degradation, partial restoration, overall restoration, time transformation, construction volume

\section{Introduction}

The term " restoration" we understand reconstruction. The experience of our country in the restoration of popular buildings makes it possible on the basis of the achievements reached to jump to more fully some basic criteria for their restoration. Popular buildings due to major transformations it has undergone over time. Any monument undergoes changes over time, but the buildings being a category directly linked with socio-economic conditions, reflects these conditions. An important role in the transformation of the building plays and numerical growth of the family and its division into new families.

\section{The purpose and objectives of the study}

It is important to conduct research on restoration, intervention methods in objects (buildings) Definitions and justifications on the restoration of residential buildings are achieved through a long investigation by the Albanian and foreign literature. The material selected is read and analyzed in such a way as to remain faithful to the theme of the handle. Everything is handled on the basis of individual opinions and conclusions based on the study of literature. Following the goal, we can determine issues of the paper in the form of the following questions.

-A Caution on new additions carried out through objects of their previous existing connection? 
-If intervene (restore) objects through a damaged original part of his predecessors?

-Interventions in a facility to enable its longevity?

\section{The study aims to:}

-To make a theoretical presentation of the way, the methods of which we intervention in the object.

-Giving some conclusions and recommendations for improving the situation.

\section{Research question, Hypothesis.}

Research questions

1. If a restored building has a more longevity?

2. What type of restoration used more partial or complete?

\section{Hypothesis}

1. Restoration of damaged parts of objects brings his longevity.

\section{The methodology of the study}

The working methodology will be qualitative research is designed so that the data gathered and interpreted to be in the middle of the target in the study.

- The resources will be used:

1. Secondary sources

2.Secondary sources: The authors and other studies of the cities history. Scientific studies by different authors.

\section{Analysis}

\subsection{Changes in time buildings}

Buildings proceed in time, this growth is reflected in the old buildings, which undergo changes. These changes can be divided into two groups:

a. In the first part make additions of new facilities that fail to alter the initial volume, often it functional. This group may include the construction of new facilities, the open areas of the apartment, which is carried out within the existing volume.

b. In the second included changes to specific architectural and constructive elements in accordance with the tastes of the time.

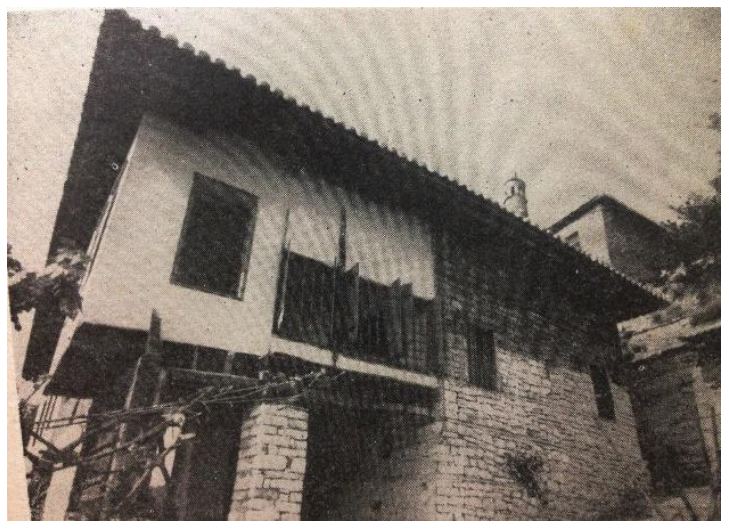

In general, in the apartment we find transformations which belong to both groups. These additions or changes and should be seen and assessed contributions of different eras that gave rise to their construction. All of these have double value as the architectural and historical document it. In many cases the additions are performed improvisations performed without any care, but simply meet immediate needs.

(Source: Monuments 11, 1972 Emin Riza fq. 162)

What is evident supplements which have not the original elements of the building, no taste, but with different materials. These types of cases should be definitely taken as seriously damage the structure of the monument, since they are located in relation to housing, also does not represent value. If extensions are attachments out of the initial volume, this action is easy and fruitful.

If the additional new facilities accepted as valid, then it is important to preserve the special treatments architectural elements that have been made to other parts of the apartment during the construction of new facilities. (Fig. No. 1) 


\subsection{Restoration of missing parts or transformed into objects}

Certainly any kind of intervention in the building is a type of damage, in the sense that affected its authenticity, its value as a product of the time and the circumstances.

However, it is a condition for the extension of the monument's life as much as possible. The term restoration must also realize the partial reconstruction of the apartment, but also thorough. Reconstruction of missing parts can be obtained from documents or data of different types. Where practiced this part? This part mainly finds use in important monuments which was severely damaged compositional unity. (Fig. No. 2, fig. No. 3)
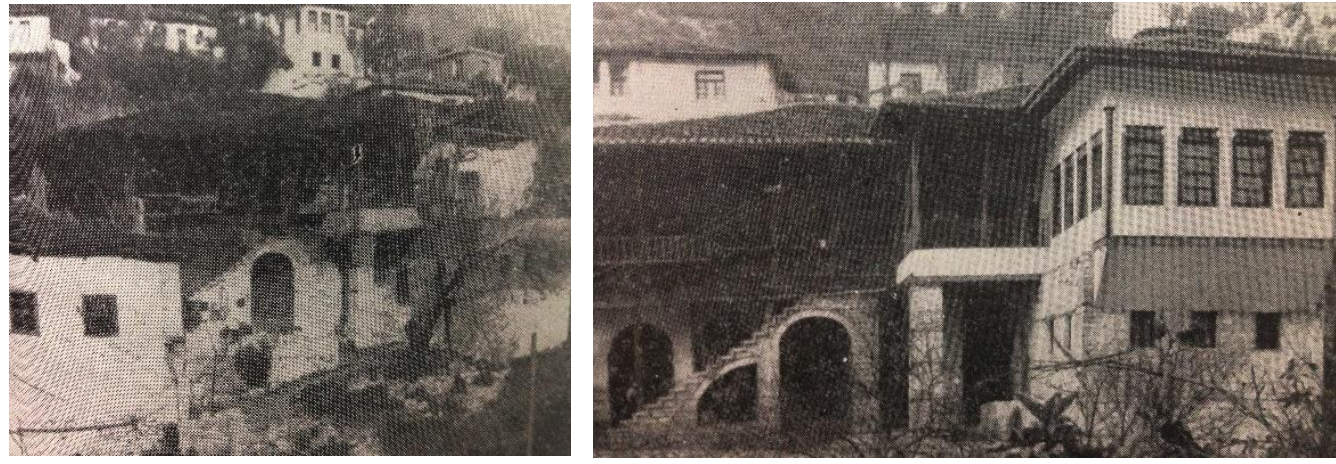

Figure 2 (Source: Monuments 11, 1972 Emin Riza p 165) Figure 3

Full restoration of the ruins requires that documentation be sufficient typical values on the initial composition. Both types of restoration and partial as it holistic seeking to preserve the original external treatment of the monument, while the inside is treated with the present conditions. There are times when the ruined parts not restored, but to highlight and consolidate the technical side. Restoration transformed parts has found wide use in practice dwellings which have been declared monuments. Parts are restored to the input of another era.

\subsection{Restoration of parts and constructive elements, architectural degraded.}

Special constructive elements and architectural monument has a double value:

a. First part of the monument itself

b. Second worthwhile in itself that in some cases pose genuine works

What we need to do and have in mind is to extend the life of structures or damaged item. Del imperative that before thinking of removing original parts reconstructed object. The materials used can be different. If we had the wood element there is the possibility of full restoration, to achieve positive results, but it would violate authenticity of the act.

Walls with any material and technical restoration should be built in to retrieve the original appearance by intensifying inside their techniques with time. Restoration and raises issues of the report, as should stay added parts to existing parts. The restored parts must be distinguished from the original. We say we have achieved good results, when part of the restored unit is included in the monument, when viewed as a whole in terms of form and material.

\subsection{The methodology of intervention}

Conservation and maintenance of various objects requires special care in the selection of materials, technologies and methodologies on which will be made restoration. These actions which follow a logical sequence that can skematizohen, final cleaning and protection. In view of the characteristics of the facility and factors (internal and external) who predominate degradation, have also chosen methodology of intervention. 
important primary characteristics in respect of any restorative interventions are:

- longevity,

- compactility

- variability

Life expectancy refers to the time permanently, characteristics and type of methodology or better product choice.

\subsubsection{Interventions cleaning}

Cleaning of constructed surfaces is a complex and delicate operation, when intervention in degraded materials, treatment of cleaning should be done careful and calibrated in such a way as not to provoke damage or drop coating.

Any interference cleaning should gradually become early using the most appropriate methods, referring to the first substance and less resistant materials, to continue with more durable materials in such a way as to capitalize more original surface, where it is possible without overlapping material.

- There are three basic criteria for choosing the most suitable system in a single case: - Efficiency: should eliminate in a more efficient manner what is harmful (dirt, etc.). - compatibility, can be considered as an application is not harmful notions, in his case the system must not cause damage eg $\therefore$ damage or porosity lëmueshmërisë the surfaces of materials. -ekonomy: first from the perspective of financial commitments, problems related to the workplace, cost etc.

\section{Cleaning techniques nowadays are numerous}

- cleaning technique with water. Which for many reasons it is rarely used nowadays. Using this method is limited. The materials are simple as natural water warm or cold and various brushes.

- with low pressure water cleaning techniques.

- mechanical cleaning.

In this type of cleaning is always the danger of falling rocks ordamage, this kind of cleaning done with soft nylon material, scalpel, tweezers, metal spatula, followed by other equipment more complicated type of dentist.

These tools operate on the basis of an electric motor and pneumatic setting in motion such materials, minor brushes with natural fiber or plastic sheeting (to clean surfaces in which are accumulated various impurities on stone, wood or metal. Plans to surfaces or less regular has found wide use abrasive paper which is fixed on wooden stoppers have the advantage they come and adapt to the surface on which the cross being deformed and simultaneously clean the surface.

With air cleaning devices. Devices in use by a small compressor

- use the whirling air Helical

- cleaning laser device.

- cleaning with chemicals.

- cleaning by absorbing clays

There are two types of clays, sepiolite, latapulgitet.

These materials have characteristic absorption of a large quantity of material in relation to their weight.

\section{Disinfection of macro and microflora}

Another cleaning process is that of the wall surface coverage: mosses, lakes, algae. The first floors of buildings are most affected this phenomenon. These arise as a result of damage caused by the chemical action of acid substances released by the radical apparatus able to chemically degrade wall surfaces. Because algae, mosses and lichens grow on the walls 
of vegetation fugaturat development puts pressure on the walls of stone or brick doing so deformed, shifting, cracked and out of centrality. Also moss or algae produce korrezive chemicals (carbonic acid). Modes of intervention:

- Resistance to oppression caused by roots action]

- The possibility of collecting roots with semi mechanisms without doing damage to the wall structure.

- operational methods for the achievement of all defective parts. Action spontaneous vegetation control and elimination should ensure greater respect for the building structure. Verification of the effectiveness of biocides observed only after 30 60 days after application.

\section{Disinfection of algae, mosses, lichens}

Mosses, algae and lakes, mainly in masonry in the damaged areas, degraded or moisture phenomena as a result of capillary condensation of moisture, one of the first steps of intervention is prohibition of moisture sources, application temperatures, high ventilation.

\section{Action climbing and stucco}

The purpose of grouting is one of the cracks filling located on the surface regardless of the origin of the crack, this type of intervention should be homogenous even the smallest cracks of stones, so that there is no possibility that the rift advance further.

The first action is that elminimit pieces of stones or supplements that are ungrounded and excess, not their elimination would lead later in the resurgence and advance of new cracks and fissures.

\section{The consolidation process}

The term refers to the consolidation of a final series of treatments which consist of improving characteristics between elements added and existing ones making this the hard way the action of water and atmospheric factors such as irritating acids.

Another goal is the consolidation of conservation of physico-mechanical virtue of material To consolidate a wall mural is an action Complex, delicate and needs careful analysis of the nature of the material and how it will be brought to interference factors.

Any intervention should be objective and Point should never be generalized. Specific criteria for the restoration of housing, due to the fact that every monument has its history and its place in the popular apartment typology, find in most cases a joint application, ie at the same monument in different parts of it can be implemented various criteria. Any restoration itself is a special case.

\section{Restoration projects and typology of restoration in Albania}

The most important period of life in Albania monuments begins with the establishment of the Institute of Defense and Restoration of Monuments, by decision No. 67 dated 03.15.1965 of the Council of Ministers, which includes ateliers of Tirana, Berat and Gjirokastra. In this regard, the year 1963 marks the beginning of the design and restoration of monuments, which is to be mentioned for example. The project sees Dyrrit Tekke in Tirana (restored by Prof. Emin Riza).

In 1981 Atelier Tirana named Branch of Monuments Tirana stretch of Lezha in Butrint as the largest branch and specializes in the protection of monuments, the territorial space defined, as well as carrying out restoration works in accordance with projects developed by specialists of the relevant sectors of the IMK. (Projects and designing its specialists, but always made their approval IMK).

With the introduction of the project, the process of restoration began to go through several stages, which have provided satisfactory results in the preservation of the monument's authenticity as structurally, and in terms of compositional and aesthetic. More specifically, these stages were: 
-comprehensive study of the monument.

-development of the restoration project.

-elaboration of conclusions

\subsection{Restorations in ancient and medieval monuments.}

Until 1945 no monument of ancient or medieval architecture was put on the defensive by the Albanian state. Archaeological work of foreign missions led by certain interests and did not provide special programs for performing restorations on the size of the protective ruins of our cities. In the years after World War II Illyrian excavations at the medieval towns passed by the empirical research stage towards concrete solutions to their problems through special in-depth studies and based on the experience of other countries.

So, in this regard, initially, people of Illyrian city fortifications system posed a number of problems for its conservation and restoration. "Waste of these systems tracts surrounding walls, defensive towers and their entrances are generally found mutilated or damaged in different time of hostilities, intimidation, or slide the terrain from rising above their vegetation and the factors others have done for centuries. (Zheku, Koco. Problems of restoration of the Illyrian city fortification systems. "Monuments", Tirana, 1976, no. 12, page 17.)

So, work on ancient monuments were mainly focused on the Illyrian cities. They, among others, as they aim for some of them to return to be visited centers where the visitor and researcher to create an idea as clear as possible for the city and Illyrian civic life. Such works were carried out for example. ancient centers of Dyrrhachium, Apollonia, Butrint other.

It is worth mentioning here the character of the conservation restoration works that were made in the perimeter walls and oak Zgërdheshit and the Apollonia Nymphaeum in Bradashesh.

As a result of careful work and close cooperation between our resturatorëve and archaeologists in these facilities was achieved quite part of them to recover. Furthermore, through this experience they were lit achieve the very important aspects of archaeologists and architects work.

In medieval monuments, ranging from the role they have played in the history of our people, priority was given protection works of the Albanian feudal principalities period, those associated with the struggle of our people against the Turkish invaders under the leadership of Skanderbeg and the time construction of independent Albanian pashaliks.

Specifically, such works were in the castle of Gjirokastra and Berat, the fortress of Kruja and Shkodra.

The goal of restorative interventions in these monuments has been returned to the museum these centers visited. In this regard, special attention is paid especially to the museum cities of Berat and Gjirokastra as an important center where the Albanian medieval city development and architecture of the Middle Ages later appear in their most complete way.

This was done for several reasons

First, these two cities retain their integrity better than any other center's former appearance, therefore Monuments Institute took care of their conservation and restoration as authentic. Unlike other centers, the problem here appeared more complicated, since we are dealing with important urban complex, in which the number of monuments protection is greater than in any other city.

Secondly, these cities continue to live and develop in accordance with the new conditions and historical circumstances. The demand of the residents who live and live in these urban centers is particularly important. In these circumstances for the protection and conservation of historic centers plays a crucial role adaptation and use of their monuments in accordance with the dynamics of life, without sacrificing historical, cultural and artistic preserve these monuments to themselves.

Achievements in the field of conservation and restoration work on ancient monuments naturally lead us to reach some conclusions: 
In the first phase, restoration work on ancient and medieval monuments have been reinforcing works or conservation works of consolidation of separate elements or parts that have lost their static stability. Such have been such. strengthening of the temple lintel of Agonothetes metal profiles, lintels of the entrance to the gate with towers and the Lion's Gate in Butrint or in the basin wall Bradashesh the other, which were consistent with the purpose of preserving the values and authentic elements of the monument. Afterwards, it is passed to the fulfillment of arcs that pose constructive need for restorative interventions such as. in the theater of Butrint, Eskulapit temple, the amphitheater, the Bradashesh terms of the other.

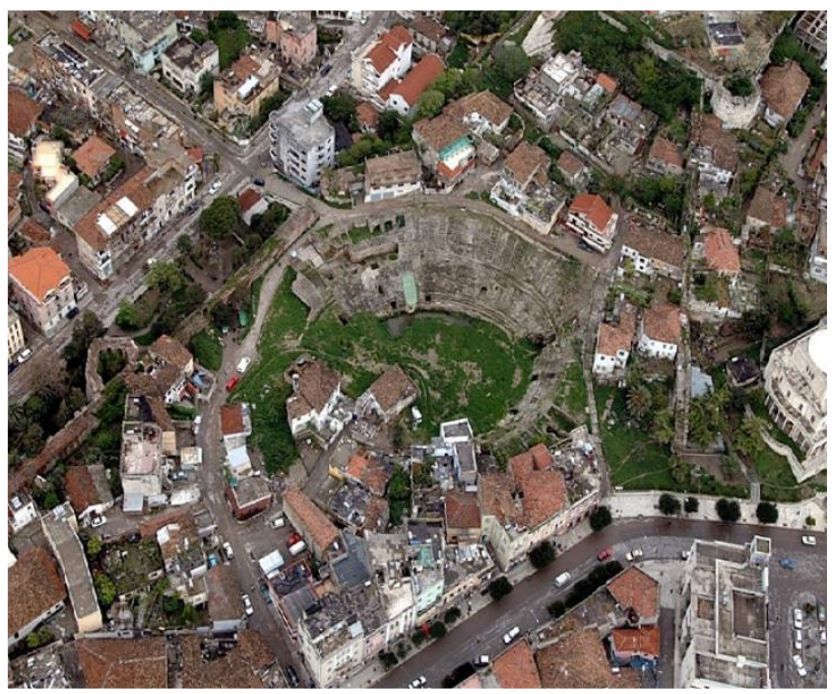

Figure 4. View of the amphitheater

Figure 5. View of the Butrint castle

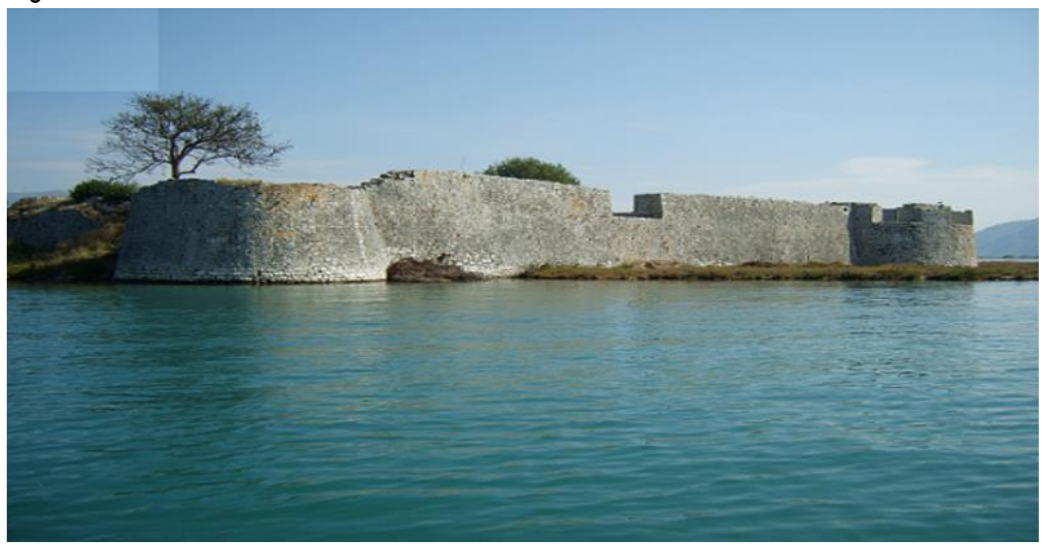

Restoration works with more complex problems we intended to preserve their artistic value. In these works is using techniques anastilozës. Problems anastilozës spread to other problems more complex in separate objects related to the necessity of full recognition of the monument by typological and its construction techniques. Likewise, the work carried out at the porch of Apollonia, the Dimal or ancient dwellings in Apollonia, Antigone and the other aimed at maintaining artistic values as a whole and individual elements in the context of certain typological solutions. The successes in this regard were 
"the result of ongoing consultations in place and constant study of the monument, standing close to the object and analyzing every trace out during restoration interventions ,.. 34

(Pani, stone, Zheku, Koco; Papajani, Lazer. The restoration of ancient monuments in our country. "Monuments", Tirana, 1988, no. 2, page 39.)

A place of great importance are also busy saving interventions. Of course, these kinds of interventions have shown a very delicate issue, therefore, require concrete or practical considerations to ensure their protection from further destruction. In these monuments to our culture, protective walls Illyrian times have been repaired or are broken and waste of these walls are used as medieval castles support bases. These materials such as blocks of fallen stones from the ancient walls, are reused in the walls of medieval fortifications with lime mortar. As the main task appeared the problem of immediate conservation to preserve intact the state of these systems, as well as come to a conclusion our archaeological excavations researchers.

In restorative practice in our country examples of interventions achieved thanks to the best knowledge of Albanian architecture history in general, specific gender monuments and history of the monument itself, are very numerous. According to our experts, one of the main goals of restoration work on the monuments of architecture and art of them has been insisting to preserve intact the history of the work, its authenticity. This has required and will require interdisciplinary research effort to benefit approach, breakthrough, and the use of modern materials, especially in the interior of the criminal structures.

As such they have been such. Use the cementation with outdated hydraulic lime layers that provide rapid solidification inside the walls or the vault and the use of synthetic resins which give the same effect. All these materials, according to our experienced restorers, guarantee the stability of the monument.

As mentioned above, the restoration of the ancient monuments of architecture generally anastylosis character. le. intervention aims to constructive and architectural re-composition to the extent that allows the material stored by each monument. In the current conditions the need for intervention in the ruins of the defensive walls of the lllyrian cities are growing both in terms of conservation, deepening the restoration works, as well as their extension in different cities.

Important qualitative step in the restoration work throughout the studies accounted for the drafting of specific restoration criteria and their application in areas such as monuments of architecture and art as well as popular apartments. This constituted important events of a scientific nature for future monuments in our country. Likewise important it was the fact of training and specialization of staff, paying attention to the new staff. So, in the fullness of attentions to the preservation and appreciation of our cultural heritage in the field of architecture and art activity haven has been waning in some chains, while in some other countries is intensifying. But self restoration activity has remained somewhat constant.

\subsection{The works of restoration in popular apartments.}

An integral part of the restoration activity that took place in our country after World War II was the restoration of residential buildings, which bear historical value in itself unique in architectural terms and in terms of meeting the immediate daily needs. According to the data we have been able to provide, we noted that the work on the restoration of residential buildings was originally launched with a slower pace, and then this activity became more organized and on the basis of a program based on scientific criteria.

The first that worked on tracking down popular buildings in our country being ethnographers, who, among others, showed special attention to popular constructions. So, in the center of their expeditions, it became the object research also popular flats, gathering data descriptive, photographic and sometimes graphics.

These initial research was extended to the countryside, as well as in the city. In our view, despite early attempts were not yet clear targets and systematic character, these efforts had great merit that gave a valuable contribution, which create the 
conditions for a significant increase in employment, as in the expansion plan both in terms of methodology and criteria of selection of folk buildings documenting the specific value.

It should be noted that the year 1959 marked an important event for the future of cultural heritage, therefore, in the field of popular constructions. Thus, the Council of Ministers decision (dt.02.06.1961) announced museum towns and cities put into state protection of Berat and Gjirokastra, and the old part of the city of Durres underground and bazaar of Kruja.

According to A. Meksi "City of Berat Regulation constitutes the first official act of putting the protection of a compound of the values of its individual facilities and environmental values, as the architectural environment, as well as natural to him ,... 39

(Mexi Alexander. The restoration of monuments of architecture. The publishing house "Eugen ,, Tirana, 2004, page 35.)

By tracing conducted in Northern Albania they were separated 55 buildings posed significant value and were put under state protection in the list of monuments year 1973. All these outstanding achievements in the field of tracing and putting the protection of folk constructions brought automatically gathering a good experience, increasing the competent scientific forces and the establishment of organizational science fair relationship between four major levels of activity for the evaluation of monuments such as: tracing, putting the protection, study and restoration.

From the work carried out by organized expeditions around the country, they were recorded about 600 rural buildings, of which 200 were put under state protection. Practically, the emergence of this important decision impose comprehensive solution to the tracking problem and putting the protection of folk constructions in our country. All this work, taking the necessary measures for its performance at the organizational level and in the methodical scientific, underwent an extensive discussion at the social sciences section of the Academy of Sciences. During this four-year intensive activities were carried out 35 expeditions and gathered a rich documentation of description, graphic and photographic. In this way, the number of rural buildings set in state protection in 1980 amounted to 210. In this period, in addition to tracking labor-intensive rural construction, was not neglected even further tracing of civic buildings, such as individual works, as well as construction ensembles. On the basis of these studies:

Besides tracing the monuments of architecture, circa 1975 it expanded job tracking offenses zbukurimores in folk dwellings. Of course, here it came to specific environments inside buildings, not kept such as architectural value were placed in state protection.

1. In 1976, it was to protect the historic center of the city of Elbasan, which included the inhabited area within the perimeter of the town's castle walls.

2. After a careful tracing of Shkodra, in 1977 were put under state protection 82 objects, generally "friends,, chamber in which preserved wooden elements chiselled in ceilings, floor screeds, doors, windows, closet lid others, as well as works in stukreliev in chimneys and rarely in ceilings.

3. In 1980 was put under state protection two architectural assembly, one in the city of Shkodra and one of Vlora.

Popular apartment has a rather specific and somewhat separate, related to two main reasons:

Firstly, because the major transformations it has undergone over time. It is true that every monument undergoes changes over time, but the apartment, being a category more directly linked to economic and social conditions, reflects these conditions expressed in class differentiation and performance of each class or social group immediately, alienated not only the composition but also the architectural treatment of the inside and the outside environment. Second, the apartment of her own nature is a construction with an intensive and permanent use to remain so even after setting a cultural monument, after the removal of residential functions would not only harm its values, but also will remove the artificial and harmful to the society it serves. 
According to prof. Riza "We can say that the report origjnale parts towards them restored have achieved good results, when part of the restored unit is included in the monument, when he perceived in its entirety and somehow distinguish the relative from the original elements, that by their shape and the material has likening .. is distinct criteria for the restoration of housing, due to the fact that every monument has its history and its place in popular tiplogjinë apartment, found in most cases a joint application, then the same monument, in different parts of it can be applied to various criteria.

(Riza, Emin. On the criteria for resturimin popular housing. "Monuments", Tirana, 1976, no. 11, page 176.)

In the Albanian case, especially until around 1990, restoration criteria in the popular apartment gender have been implemented, we would say consistent target and reach, with the method set out in the Charter of Venice Restoration. This can be traced to the large number of restored monuments, but also of programmatic document "Criteria for the restoration of cultural monuments of architecture and art,, adopted by the Committee on Culture and Arts, on February 10, 1986. Due to the consideration with minor value, as well as in developed countries, we believe that folk architecture remained out settings "monument,, (Riza, Emin: popular architecture and its assessment. publishing House" Day 2000 ", Tirana, 2013, page 12)

Further, the change of the political regime and the transition to a democratic system in the field of protection of monuments has brought stagnation to circa 2000. According to prof. E. Riza, there are two main reasons for this situation:

First, disregard of professionalism as an essential condition for selected staff of specialists by area.

Second, the rapid changes, as well as positive lifestyle, which do not conform to traditional apartment, which nowadays and further, regarding the use in its operation, will file a growing problem

\section{QUESTIONNAIRE}

1. Are encountered before the term "restoration"?

\begin{tabular}{|l|l|l|}
\hline & Yes & No \\
\hline$\%$ of answer & $25 \%$ & $75 \%$ \\
\hline
\end{tabular}

Figure $6.1 \%$ of answer for the term "Restauration".

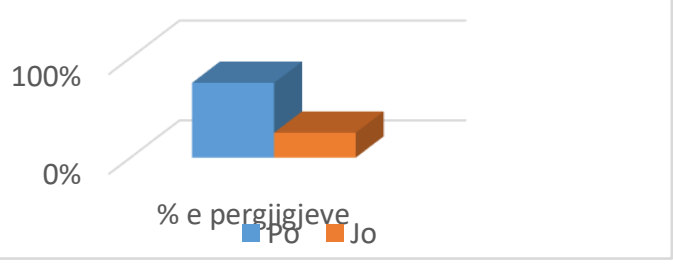

Figure 6.2 Graphic I \% of answer for the term "Restauration".

Conclusions: According to the above graph shows that about $25 \%$ are familiar with the term restoration and function, while $75 \%$ had not heard of before this term or what the function does.

2. Do you think that the restoration affects the longevity of the building?

\begin{tabular}{|c|c|l|c|}
\hline & Yes & Maybe & No \\
\hline$\%$ of answer & $79 \%$ & $16 \%$ & $5 \%$ \\
\hline
\end{tabular}

Figure 6.3 percent \% of answer to influence the longevity of the building. 


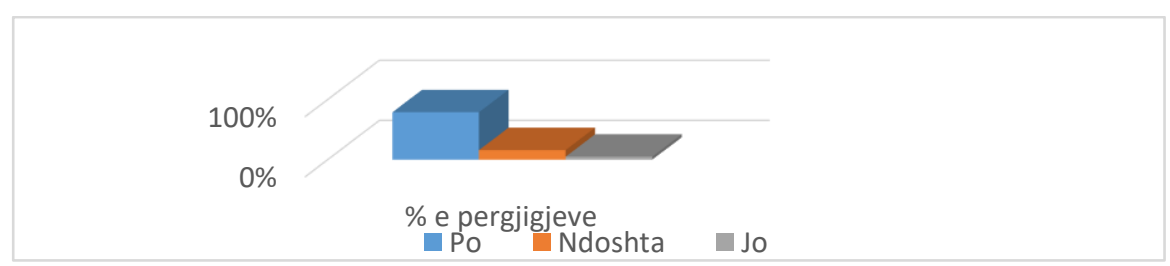

Figure 6.4 Graphic I \% of answer to influence the longevity of the building.

Conclusions: According to statistics, $79 \%$ confirmed that the restoration of buildings affect their lifespan, $16 \%$ think that the impact is minimal while $5 \%$ to restoring the site does not cause any kind of impact in buildings.

3.Do you know which are the materials The materials used in restoration of the buildings?

\begin{tabular}{|l|l|l|l|}
\hline & Yes & Maybe & No \\
\hline$\%$ of answer & $10 \%$ & $20 \%$ & $70 \%$ \\
\hline
\end{tabular}

Figure $6.5 \%$ of answer regarding the recognition of materials.

Conclusions: According to statistics, $10 \%$ confirmed that recognize the materials used in the restoration of buildings, $70 \%$ do not recognize them, while $20 \%$ think that they know the materials used.

4.A mendoni se Shqipëria,si vend në zhvillim, duhet të restauroje godina?

\begin{tabular}{|l|l|l|l|}
\hline & Yes & Maybe & No \\
\hline$\%$ of answer & $86 \%$ & $9 \%$ & $5 \%$ \\
\hline
\end{tabular}

Figure 6.7 Table $\%$ of responses for the restoration of buildings.

\section{Graphic :}

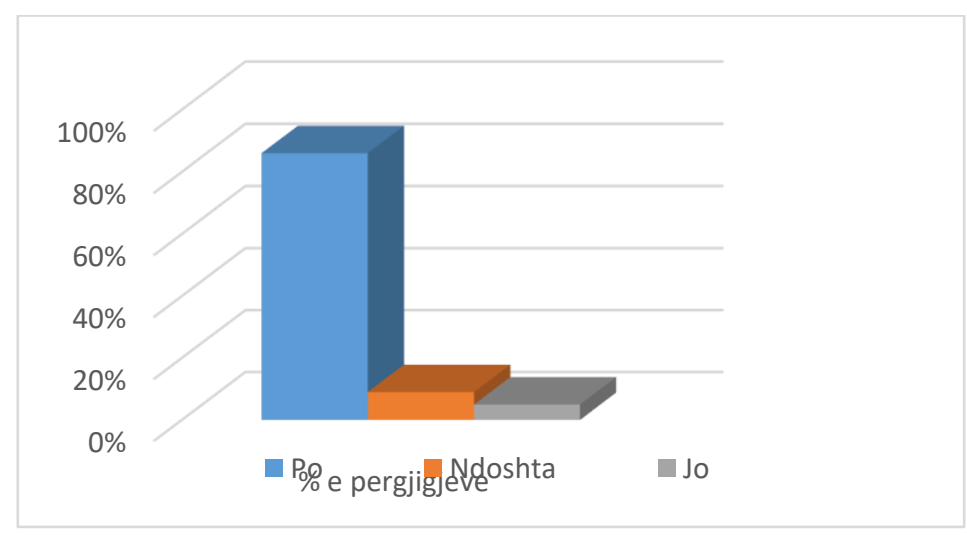

Figure $6.8 \mathrm{Graph} \%$ of the responses for the restoration of buildings.

Conclusions: As can be seen from the above study $86 \%$ are of the opinion that Albania must restore the building, then have $9 \%$ who think it is difficult to achieve, but not impossible. Finally, $5 \%$ are against the restoration.

5. What the restoration material most commonly used wood, metal, plastic or glass? 
Figure $6.9 \%$ of the answers to the most commonly used material

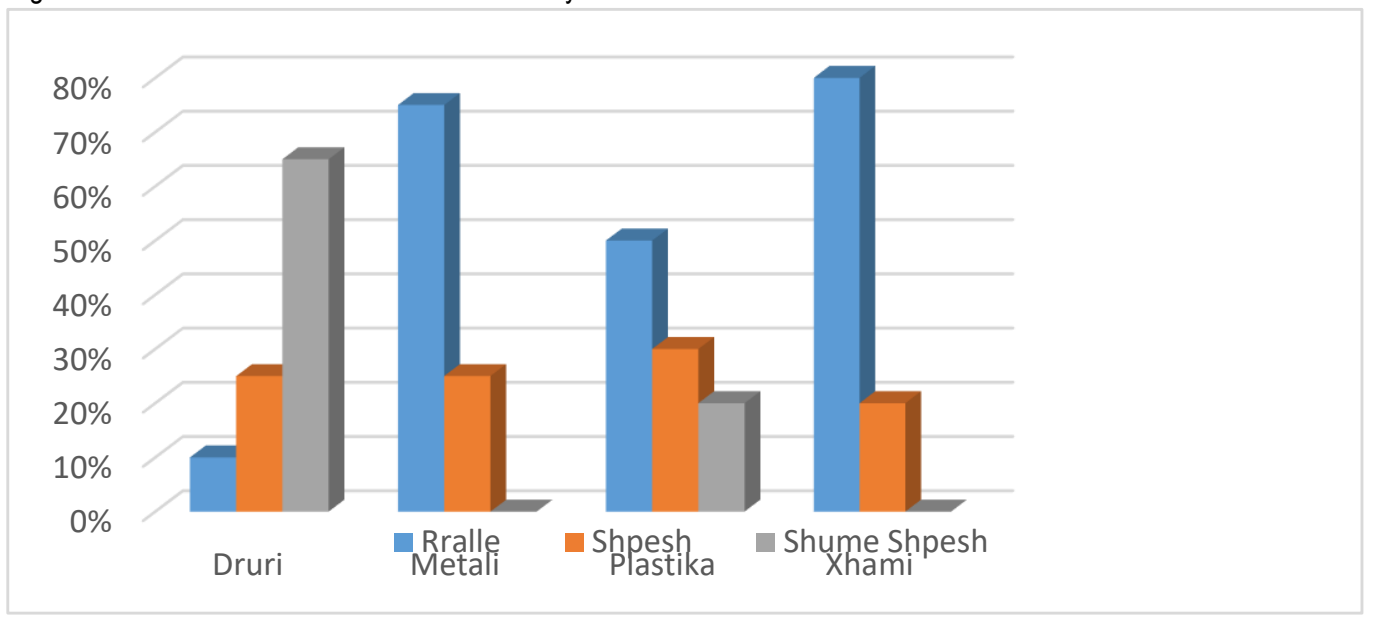

Figure 6.10 Graphic I \% of answer to the material used in the buildings.

Conclusions: According to statistics obtained from this interview materials which are used more wood and plastics with $65 \%$ to $20 \%$. While $75 \%$ of metal is very rare in its use in interiors or eksteriore, with glass which has $80 \%$ rarely use.

\section{Questionnaires:}

Number of respondents: 100 persons, who were of different professions. Number 58 women and 42 men. Their average age 37 years old.

\section{7._Conclusions and Recommendations}

In this period, significant qualitative step in the restoration work throughout the studies accounted for the drafting of specific restoration criteria and their application in areas such as monuments of architecture and art as well as popular apartments.

In medieval art it is performed to the best activities for their protection and restoration, by clearly defining the criteria for restorative intervention in these works. In the practice of restoration work on the monuments stemming from archaeological excavations has been a close coordination with the archaeologist Restauratori work.

An integral part of the restoration activity that took place in our country after World War II was the restoration of residential buildings, which bear historical value in itself unique in architectural terms and in terms of meeting the immediate daily needs. Work on the restoration of residential buildings, originally started more slowly, and, later, became more organized and built on scientific criteria.

Should show special care in New Accessories performed through objects, their relationship with the original part of the building.

Any kind of intervention in the apartment is a type of damage, in the sense that affected its authenticity, its value as a product of the time and the circumstances, but it is a condition for extending the life of the monument as much as mundur. Restaurimi full of rubble requires that documentation be sufficient typical values on the initial composition. Restoration transformed parts has found wide use in practice dwellings which have been declared monuments.

In this period, significant qualitative leap around the restoration work comprised of studies of the design of specific criteria restoration and their application in areas such as monuments of architecture and art and apartments - It turns out that about 
$25 \%$ are known the restoration of the term and its function, while $75 \%$ had not heard of before this term or what the function does.

- According to statistics, $79 \%$ confirmed that the restoration of buildings affect their lifespan, $16 \%$ think that the impact is minimal while $5 \%$ to restoring the site does not cause any kind of impact in buildings.

- According to statistics, $10 \%$ confirmed that recognize the materials used in the restoration of buildings, $70 \%$ do not recognize them, while $20 \%$ think that they know the materials used.

- As can be seen from the above study $86 \%$ are of the opinion that Albania must restore the building, then have $9 \%$ who think it is difficult to achieve, but not impossible. Finally, $5 \%$ are against the restoration.

- According to statistics obtained from this interview materials which are used more wood and plastics with $65 \%$ to $20 \%$. While $75 \%$ of metal is very rare in its use in interiors or eksteriore, with glass which has $80 \%$ rarely use.

\section{BIBLIOGRAPHY:}

[1] D. Spinelli 2005 "Insediamenti rurali e masserie nel territorio di Cisternino di Brindisi" Adriatica Editrice - Bari

[2] E. Daci "Leksione te shkruara"

[3] E. Riza, 1972 "Monumentet 11"

[4] E.Berardi, A.M.Mecchi, A.Calia, M.Lettieri, 2002 - Waterrepellent treatments on some calcareous Apulian stones of differing porosity, in 5th International Symposium on The Conservation of Monuments in the Mediterranean basin, Seville, Spain, 2000, Protection and Conservation of the Cultural Heritage of the Mediterranean Cities, Gàlan and Zezza (eds), Swets and Zeitinger, Lisse, pp. 401-406.

[5] G.Calò, M.Di Pierro, A.Federico, G.Mongelli. 1195 - Caratteri geologici petrografici mineralogici e meccanici dei carpari della provincia di Lecce . Quarry and Construction Ed. PEI Parma. Linee Guida per l'applicazione al patrimonio culturale della normativa tecnica di cui all'Ordinanza P.C.M. 3274/2003

[6] M.C.Caputo, E.Quadrato, \& N.Walsh, 1996 - Influenza dello shock termico sui parametri fisico-meccanici del tufo calcareo del bordo occidentale delle Murge. Mem. Soc. Geol. It. 51, 813-822.

[7] P.Marino, C.Samugheo 1993 "Le corti del verde - Viaggio per le masserie di Puglia e Basilicata" Edisud.

[8] Ambrosi, E. Degano, C.A. Zaccaria, 1990 "Architettura in pietra a secco" Schena Editore 